\title{
PREFERENSI KONSUMEN PADA AKTIVITAS CALLBACK DAN TELEMARKETING DI RESTORAN CEPAT SAJI
}

\author{
Rida Zuraida \\ Industrial Engineering Department, Faculty of Engineering, Binus University \\ Jl. K.H. Syahdan No. 9, Palmerah, Jakarta Barat 11480 \\ rida.zuraida@gmail.com
}

\begin{abstract}
This paper is objected to proposed a model for delivery service at fast food restaurants to measure consumer's preferences of callback and marketing activities. The model is developed using 4C concept (customer value, customer cost, customer convenience and customer communication). The concepts that used here are supported by previous researches on restaurant related to consumer behavior, and the theories of marketing activities including marketing and communications impact. For next steps, the measurement model should be implemented to see how far the reliability of the proposed model, and what improvements can be done in order to obtain a better model. The result can be used to develop strategies of callback and telemarketing activities for delivery service at fast food restaurant, which suit as as customer expectation and company's resources.
\end{abstract}

Keywords: consumer's preferences, 4C, direct marketing, callback, telemarketing, fastfood restaurant

\begin{abstract}
ABSTRAK
Paper ini dimaksudkan sebagai usulan pengukuran preferensi konsumen terhadap aktivitas callback dan telemarketing pada jasa layanan antar restoran cepat saji. Model dikembangkan berdasarkan konsep 4C (customer value, customer cost, customer convenience dan customer communication), penelitian mengenai restoran dan perilaku konsumen yang sudah banyak dilakukan, serta teori aktivitas pemasaran termasuk komunikasi pemasaran dan dampaknya. Untuk selanjutnya usulan model pengukuran perlu diimplementasikan untuk melihat sejauh mana realibilitas model yang diusulkan, serta perbaikan apa yang dapat dilakukan agar diperoleh model yang lebih baik. Dipetakannya preferensi konsumen terhadap aktivitas tersebut diharapkan dapat menjadi landasan bagi restoran waralaba untuk mengembangkan strategi kegiatan callback dan telemarketing yang sesuai dengan kebutuhan konsumen serta sumber daya yang dimiliki oleh perusahaan.
\end{abstract}

Kata kunci: preferensi konsumen, 4C, pemasaran langsung, call back, telemarketing, restoran cepat saji 


\section{PENDAHULUAN}

Salah satu alasan perkembangan yang cepat dari restoran cepat saji terutama jenis waralaba, dikarenakan kemampuan utuk memberikan jasa layanan antar (Pickworth, 1988). Akan tetapi, layanan ini secara generik dapat dikembangkan oleh semua jenis industri makanan. Saat ini, khususnya bagi restoran cepat saji, jasa layanan antar menjadi salah satu strategi bersaing, terutama di era telekomunikasi seperti sekarang.

Beberapa restoran cepat saji beberapa tahun terakhir mulai menggalakkan layanan jasa antar (delivery service) sebagai sales point yang ditangani secara serius seperti penanganan gerainya. Salah satu restoran cepat saji di Indonesia sejak tahun 2003, memiliki layanan call center untuk menangani pemesanan jasa antar di seluruh Indonesia. Call center ini dimaksudkan untuk menjadikan jasa layanan antar sebagai profit center dengan persentase penjualannya telah mencapai 30\% dari total keseluruhan penjualan. Restoran cepat saji lainnya secara serius memulai jasa layanan antar secara nasional pada tahun 2010, dan saat ini penjualannya baru mencapai 8\% dengan target 30\%. Restoran cepat saji lainnya yang menyediakan makanan jepang, dan baru melayani wilayah Jabodetabek dan Cilegon mentargetkan pendapatan dari jasa layanan antar sebesar 50 persen dari seluruh penjualannya (B.S \& Nugroh, 2009). Berbagai jenis restoran yang menyajikan menu makanan lokal sudah lama menyediakan jasa layanan antar sebagai jenis layanan wajib yang tersedia, bahkan penjual makanan mulai dari kaki lima pun menyediakan layanan ini dalam lingkup lokasi terbatas.

Strategi bersaing tidak lagi akan menjadi strategi yang memiliki keunggulan jika strategi tersebut sudah menjadi strategi generik. Sehingga selain menyediakan jasa layanan antar dengan menyediakan nomor khusus, strategi lain perlu dilakukan oleh pengusaha restoran. Beberapa aktivitas yang biasa dilakukan adalah telemarketing produk kepada pelanggan atau calon pelanggan potensial.

Untuk meningkatkan efektivitas kegiatan pemasaran, perusahaan memerlukan database konsumen yang terkomputerisasi, informasi konsumsi serta informasi strategi dan taktik yang sesuai (Nowak \& Phelps, 1997). Kesuksesan aktivitas pemasaran diketahui berhubungan positif dengan ketersediaan informasi konsumsi di level individual. Secara umum, teknologi, orang, serta informasi memiliki peran penting dalam menjalankan aktivitas pemasaran dewasa ini (Mulyadi, 2010).

Jasa layanan antar yang difasilitasi perlengkapan call center yang canggih, perusahaan dapat memiliki catatan telpon untuk aktivitas telemarketing atau panggilan kembali berdasarkan telepon yang tidak terjawab di jam sibuk. Hal ini dimungkinkan karena tersedianya rekaman data telepon keluar dan masuk tercatat secara sistem. Dari data yang disediakan secara sistem aktivitas outbound (panggilan keluar) dapat dilakukan oleh petugas khusus atau bukan petugas yang menangani inbound (panggilan masuk). Semakin canggihnya teknologi memungkinkan perusahaan memiliki data konsumen yang dapat digunakan untuk kegiatan marketing dan menjadi kekuatan perusahaan dalam bersaing dengan perusahaan lain (Stone \& Shaw, 1987).

Kegiatan call back dan telemarketing merupakan strategi yang telah dijalankan oleh beberapa restoran. Akan tetapi belum ada penelitian mengenai preferensi konsumen terhadap kedua aktivitas ini. Artikel ini membahas alat ukur yang dapat digunakan dan dimaksudkan untuk digunakan agar perusahaan dapat melakukan survei tentang bagaimana konsumen merespon aktivitas call back dan telemarketing dari suatu pusat jasa layanan antar yang menjadi favoritnya.

Penelitian mengenai alat ukur menjadi penting, karena untuk dapat memperoleh hasil survei yang baik sebagai input strategi perusahaan, tentu saja diperlukan pengukuran yang baik termasuk di dalamnya alat ukur, metoda pengumpulan data serta pengolahannya, dan responden yang sesuai dengan profil konsumen. Pentingnya pemahaman mengenai bagaimana preferensi konsumen, dan mengenai cara pengukurannya menjadi latar belakang utama penelitian ini dilakukan. 


\section{METODE}

Metode yang digunakan adalah penelurusan teori dan penelitian terdahulu untuk menyusun alat ukur preferensi konsumen pada jasa layanan antar yang diberikan oleh restoran cepat saji. Penyusunan didasarkan pada penelitian lain menyarankan untuk memiliki data pelanggan yang baik jika ingin memenangkan persaingan (Nowak \& Phelps, 1997), memiliki mengenai bagaimana pelanggan memandang produk atau jasa yang diberikan perusahaan (Brezen, Block, \& Schultz, 1987), dan telemarketing yang merupakan tren teknik pemasaran langsung saat ini. Penelitian juga menyarankan agar mentargetkan konsumen yang terbiasa melakukan kontak melalui multichannel. Untuk membentuk konsumen yang lebih loyal dalam pemesanan layanan antar perusahaan disarankan untuk menggunakan multichannel dalam memberikan pelayanan.

Alat ukur yang dikembangkan dimaksudkan sebagai dasar perusahaan dalam membangun strategi pemasaran langsung dengan memanfaatkan data konsumen yang diperoleh melalui pemanfaatan teknologi contact center yang dimiliki oleh perusahaan. Sedangkan aktivitas pemasaran langsung yang dimaksud adalah telemarketing dan callback dan model bertujuan untuk memperoleh respon konsumen terhadap kedua aktivitas tersebut. Diharapkan model ini dapat dijadikan acuan bagi perusahaan untuk mengetahui preferensi konsumen sebelum aktivitas telemarketing dan callback dijalankan, sehingga pelaksanaannya sesuai dengan kebutuhan, dan keinginan pasar sasaran (Kotler, Marketing Management, 2003).

Variabel dirumuskan berdasarkan konsep 4P (product, price, promotion, and place) (Kotler, 2009) di mana produk merupakan customer value, price sebagai customer cost, promotion sebagai customer communication dan place sebagai customer convenience. Hasilnya berupa kuesioner yang disusun berdasarkan teori yang dijabarkan pada bagian berikutnya. Kuesioner yang disusun diharapkan menjadi instrumen dengan realibilitas yang baik sehingga dapat digunakan dalam penelitian selanjutnya.

\section{Pemasaran dan 4C}

Konsep pemasaran menyatakan bahwa kunci untuk meraih tujuan perusahaan adalah menjadi lebih efektif daripada pesaing dengan memadukan kegiatan pemasaran dalam menciptakan dan memuaskan kebutuhan dan keinginan pasar sasaran (Kotler, Marketing Management, 2003).

Untuk memahami keinginan pasar sasaran dalam hal ini pembeli, pemasar perlu mempelajari ilmu perilaku dan organisasi dan memanfaatkan informasi mengenai demografi, psikologi, budaya dan pengaruh sosial. Atas informasi yang dimiliki, maka perusahaan dapat mengembangkan strategi yang lebih efektif sesuai dengan kebutuhan, persepsi, keinginan, dan perilaku konsumen (Kotler, According to Kotler, 2005).

Kotler juga mempopulerkan model konsep bauran pemasaran yang dikenal dengan 4P, yaitu product, price, promotion dan place. Konsep 4P kemudian berkembang menjadi 4C, yaitu product sebagai customer value, price sebagai customer cost, place sebagai customer convenience dan promotion sebagai customer communication (Kotler, 2005).

Bauran pemasaran yang dikenal dengan 4P ini atau sekarang 4C, akan efektif jika mencapai tujuan dan sasaran pemasaran, memenuhi kebutuhan konsumen, konsisten dan seimbang, dapat menciptakan manfaat yang kompetitif, serta sesuai dengan sumber daya yang dimiliki oleh perusahaan (Kotler, Marketing Management, 2003). 
Perusahaan diharapkan tidak hanya menghasilkan produk tetapi menyampaikan sesuatu yang bernilai sesuai harapan konsumen. Customer value juga didefinisikan sebagai persepsi terhadap benefit yang diperoleh konsumen dari produk ataupun jasa relatif terhadap biaya yang dikeluarkan. Nilai yang ditawarkan ini merupakan paket yang terdiri dari variasi produk, kualitas, desain, fitur, nama merek, pengemasan, ukuran, pelayanan serta layanan purna jual.

Biaya konsumen berkaitan tidak hanya dengan harga produk atau jasa itu sendiri, tetapi juga biaya yang dikeluarkan sebelum dan sesudah melakukan pembelian produk atau jasa. Biaya yang dilihat oleh pelanggan antara lain daftar harga produk, diskon yang diberikan, kemudahan, serta cara pembayaran. Jika produk atau jasa yang diperoleh dianggap memiliki nilai lebih tinggi, maka konsumen bersedia membayar lebih banyak dibandingkan dengan yang tidak.

Kenyamanan pelanggan berhubungan erat dengan kemudahan yang mungkin diperoleh konsumen. Kemudahan tersebut yang semula disebut sebagai place ataupun distribusi produk/jasa, bisa berupa tersedianya cabang, cakupan area pelayanan, lokasi, ketersediaan barang, serta transportasi yang berkaitan dengan penyediaan, pengangkutan dan logistic produk (Kotler, Marketing Management, 2003).

Komunikasi pelanggan, berkaitan dengan mengkomunikasikan keunggulan produk dan nilai yang akan tawarkan kepada pelanggan tidak hanya berupa promosi iklan ataupun promosi penjualan. Promosi penjualan berkaitan dengan peningkatan penjualan, sementara promosi iklan berkaitan dengan positioning serta pembentukan brand image produk/jasa kepada pelanggan (Kotler, According to Kotler, 2005).

Kotler (2003) juga mengajukan konsep promotional mix yang bergantung dari tahapan siklus produk, di mana di tahap awal sangat penting untuk melakukan iklan, pemberian informasi tentang produk atau jasa yang terkait, pemahaman akan kompetisi, budget untuk aktivitas marketing, strategi marketing itu sendiri, serta target market yang tepat.

Adapun elemen dalam bauran promosi antara lain iklan, bisa melalui press, radio, TV, iklan outdoor, press release, identitas perusahaan, kegiatan branding, personal selling, sponsorship, telemarketing, internet marketing, pameran, dan lain sebagainya.

Secara keseluruhan, 4C mewakili keinginan customer terhadap nilai total cost yang rendah, kenyamanan yang tinggi, dan komunikasi bukan hanya promosi.

Park (2004) dalam penelitiannya menggunakan dua konsep consumer value untuk menggambarkan konsumen fast food di Korea yaitu hedonic dan utilitarian value. Hedonic value dideskripsikan sebagai konsep yang lebih subjektif dan personal, berkaitan dengan kesenangan dan kegembiraan (Holbrook \& Hirschman, 1982). Sedangkan perilaku konsumen pada konsep utilitarian dideskripsikan sebagai task-related and rational (Batra. \& Ahtola, 1991). Hasil penelitiannya menunjukkan, hedonic value ternyata memiliki korelasi positif dengan mood, pelayanan yang cepat, kebersihan, rasa makanan, keramahan pegawai, dan fasilitas yang tersedia. Sedangkan utilitarian value berhubungan dengan harga yang dianggap wajar, pelayanan yang cepat serta harga promosi. Pelayanan yang cepat serta promosi berupa insentif harga berhubungan dengan kedua value. Hal ini diartikan bahwa pelayanan yang cepat merupakan atribut dasar dari restoran cepat saji bagi kedua value, dan promosi berupa insentif termasuk diskon, acara khusus serta promosi penjualan juga termasuk ke dalam keduanya. Artinya keduanya merupakan atribut dasar . Hasilnya menunjukkan frekuensi pembelian lebih dipengaruhi oleh hedonic value dibandingkan utilitarian value (Park, 2004).

Penelitian mengenai perilaku pembelian di restoran cepat saji di Turki (Akbay \& Tiryaki, 2007) menunjukkan frekuensi pembelian di restoran cepat saji dipengaruhi oleh umur, pendapatan, tingkat pendidikan, besarnya rumah tangga, jumlah anak dan faktor lain seperti harga, pertimbangan 
kesehatan dan pilihan yang disukai oleh anak. Selain itu Dagevos (2005), menyatakan bahwa perilaku konsumsi di masyarakat modern tidak lagi dapat dipahami secara langsung dan melalui pengukuran segmentasi saja. Untuk memahami kompleksitas perilaku, disarankan agar memiliki pemahaman mengenai socio-cultural, socio-psychological, selain socio demografi (contoh usia, jenis kelamin) ataupun socio-economy (contoh: pendapatan, pekerjaan) yang biasanya digunkan pada penelitian mengenai konsumsi. Lebih jauh Park (2004) menyebutkan bahwa variabel intermediate seperti umur konsumen, tingkat pendapatan, pilihan rasa, lokasi, dan lain sebagainya perlu diteliti lebih jauh berkaitan dengan nilai konsumen untuk perilaku pembelian di restoran cepat saji.

Penelitian yang dilakukan oleh Cardello dkk (2000) mengenai kepuasan konsumen terhadap makanan yang dikonsumsi pada jam makan siang, menunjukkan bahwa persepsi konsumen mengenai suka atau tidak suka terhadap suatu jenis makanan, dipengaruhi oleh kualitas makanan dan kecocokan jenis makanan dengan waktu makan. Dalam situasi nyata, cukup sulit memprediksi berbagai aspek perilaku konsumen yang berhubungan dengan makanan (Cardello, Schutz, Snow, \& Lesher, 2000). Akan tetapi hasil penelitian ini menunjukkan bahwa waktu makan juga bisa mempengaruhi konsumen dalam memilih menu, hal ini berkaitan dengan budaya dan kebiasaan mengenai apa yang lebih cocok dimakan untuk jam makan tertentu.

\section{Pemasaran Langsung}

Penelitian di area pemasaran langsung, perlu lebih mendalami mengenai bagaimana konsumen memandang berbagai jenis teknik pemasaran langsung, bagaimana konsumen memandang dirinya berhubungan dengan setiap teknik. Kedua hal ini penting bagi perusahaan yang melakukan teknik pemasaran langsung (Brezen, Block, \& Schultz, 1987). Teknik pemasaran secara langsung yang umum dilakukan selain tenik dari pintu ke pintu, adalah melalui media pos yang digabungkan dengan tagihan kartu kredit atau rekening koran dalam bentuk katalog belanja. Teknik ini dilakukan baik secara elektronik maupun non-elektronik. Teknik lain yang sekarang menjadi trend adalah melalui aktivitas telemarketing.

Target konsumen dari aktivitas pemasaran langsung, termasuk telemarketing, secara umum menyasar konsumen tetap perusahaan ataupun calon konsumen potensial. Menentukan konsumen mana yang lebih berpotensi akan melakukan pembelian baik dari konsumen tetap maupun calon konsumen, merupakan hal yang sulit. Tetapi berdasarkan hasil penelitian Kumar dan Vankatessan (2005), konsumen yang membeli berbagai jenis kategori produk dari suatu perusahaan, umumnya merupakan konsumen yang lebih sering menghubungi perusahaan, pernah mengontak call center melalui berbagai channel komunikasi, melakukan pembelian lebih sering, serta berhubungan dengan call center secara pribadi. Hasil penelitiannya juga menunjukkan bahwa konsumen yang melakukan pembelian melalui berbagai channel, merupakan konsumen yang menguntungkan bagi perusahaan karena memberikan revenue yang lebih besar (Kumar \& Venkatesan, 2005).

\section{Teknologi dan Pelayanan}

Teknologi yang berkembang saat ini, dimanfaatkan oleh perusahaan untuk memberikan pelayanan dan menyediakan kontak kepada konsumen melalui berbagai channel. Pada jasa layanan antar, ketersediaan jaringan telpon dimanfaatkan untuk memberikan layanan ini. Pada beberapa restoran waralaba cepat saji di Indonesia, telah dimanfaatkan teknologi call center untuk layanan ini. Dulu call center hanya digunakan untuk mengumpulkan sebanyak mungkin informasi tentang pelanggan dan mengumpulkan semua order yang masuk. Tetapi, saat ini teknologi yang digunakan di call center dapat menampung kegiatan transaksi yang ada, sehingga perusahaan bisa mendapatkan pola dan tren dari aktivitas call center, dari channel apa pun yang digunakan baik melalui voice ataupun data. Call center yang memanfaatkan berbagai chanel ini lebih dikenal dengan sebutan contact center (voice/telepon, sms, email, fax, media jejaring sosial, dan lain-lain). Teknologi contact center yang ada sekarang, memungkinkan perusahaan memiliki rekaman histori kegiatan setiap kali 
konsumen menghubungi, memiliki sistem penyaring untuk menyalurkan kontak dari konsumen ke agen yang tepat untuk setiap channel kontak, sehingga waktu tunggu konsumen dapat dikurangi (Suryanto, 2011; Mulyadi, 2010).

Teknologi juga memungkinkan perusahaan untuk membangun basis data pelanggan yaitu kumpulan data komprehensif yang terorganisir tentang pelanggan dan calon pelanggan individual yang selalu diperbaharui. Teknologi juga memungkinkan perusahaan dapat mengaksesnya sehingga dapat dimanfaatkan untuk mencapai tujuan-tujuan pemasaran seperti: (1) identifikasi calon pelanggan, (2) kualifikasi calon pelanggan, (3) prospek penjualan produk atau jasa, atau (4) strategi pemeliharaan hubungan pelanggan

Basis data pelanggan memungkinkan perusahaan untuk membangun basis data pemasaran yaitu berupa pembentukan, pemeliharaan, serta pemakaian basis data pelanggan dan basis data lain (produk, pemasok, pedagang kembali/reseller) dengan tujuan untuk berhubungan dengan pelanggan dan bertransaksi. Basis data pelanggan ini dibentuk berdasarkan informasi yang diperoleh perusahaan dan bisa saja terdiri dari data demografis, data pembelian terdahulu, serta informasi individual lain yang relevan.

\section{Komunikasi dan Dampak Komunikasi Pemasaran}

Komunikasi dapat diartikan sebagai proses peralihan dan pertukaran informasi oleh manusia melalui adaptasi dari dan ke dalam sebuah sistim kehidupan manusia dan lingkungannya. Proses peralihan dan pertukaran informasi itu dilakukan melalui simbol-simbol bahasa verbal maupun nonverbal yang dipahami bersama.

Schramm dan Robert (1977) mengemukakan lima pengertian komunikasi yang dikutip dari beberapa sumber: (1) Komunikasi adalah suatu proses pemberian, penyampaian, atau pertukaran gagasan, pengetahuan, dan lain-lain yang dapat dilakukan melalui percakapan, tulisan, atau tandatanda.(Oxford English Dictionary); (2) Komunikasi adalah proses pengalihan pikiran dan pesan-pesan seperti sarana transportasi mengangkut barang dan manusia; (3) suatu sistem yang di dalamnya terkandung sumber, pengaruh terhadap orang lain, tujuan atau sasaran yang melaksanakan rangkaian kegiatan dengan memanipulasi pilihan tanda tertentu yang dapat dialihkan melalui saluran tertentu; (4) meliputi prosedur yang mengatur bagaimana pikiran mempengaruhi orang lain; (5) mekanisme hubungan antarmanusia yang menyebabkan manusia itu bertahan dan berkembang melalui penyampaian simbol pikiran melalui suatu ruang dan waktu tertentu.

Adapun dampak dari aktivitas komunikasi pemasaran dirumuskan oleh Lavidge dan Steiner (2000) termasuk di dalamnya dampak jangka panjang. Pada konsumen yang sama sekali tidak mengenal produk, terdapat 6 tahapan sebelum konsumen akhirnya melakukan pembelian, yaitu 1) awareness, yaitu konsumen menyadari keberadaan produk atau jasa; 2) knowledge, yaitu konsumen mengetahui mengenai fitur dan kegunaan dari produk atau jasa; 3) liking, konsumen memiliki rasa suka terhadap produk; 4) preference, konsumen mengembangkan preference dibandingkan terhadap produk pesaing ataupun produk pengganti; 5) conviction, tahap ini merupakan tahap di mana konsumen merasa yakin produk atau jasa tersebut layak untuk dibeli; dan 6) purchase, konsumen melakukan pembelian.

\section{Konsumen sebagai CoProduser}

Salah satu ciri yang membedakan jasa dengan manufaktur adalah peran konsumen dalam proses produksinya. Di industri jasa, konsumen berperan dalam prosesnya, sementara di manufaktur tidak. Kebutuhan tingkat keaktifan konsumen bervariasi dari satu jenis jasa dengan jenis jasa lainnya dan dipengaruhi oleh sistem pelayanan yang dikembangkan oleh usaha itu sendiri. Perusahaan yang menggunakan pendekatan konsumen sebagai coproduser akan mendesain sistemnya untuk agar 
konsumen lebih terlibat di semua proses pelayanan. Begitu juga dalam sebuah sistem jasa layanan antar, peningkatan peran serta konsumen dapat ditingkatkan. Ketersediaan teknologi memungkinkan proses pemesanan bisa dilakukan secara sistem dengan konsumen yang berperan sebagai operator yang memasukkan pesanan ke dalam sistem. Hal ini dapat mengurangi kesalahan item yang dipesan, meningkatkan kepuasan konsumen serta mengurangi jumlah sumber daya yang harus disediakan perusahaan.

Kemudahan pemesanan dengan penyediaan multichannel oleh perusahaan, merupakan daya tarik yang bisa menjadi nilai jual produk terhadap konsumen. Peningkatan peran konsumen dalam proses jasa melalui multichannel dapat mendukung strategi bersaing melalui cost leadership dengan beberapa penyesuaian dan fokus terahap konsumen yang tertarik untuk terlibat dalam proses pelayanan (Fitzsimmons, 2011).

\section{HASIL DAN PEMBAHASAN}

Uraian pada bagian metode termasuk teori yang digunakan kemudian disusun untuk membuat kerangka pikir mengenai alur yang menjadi input penyusuan strategi perusahaan pada kegiatan callback dan telemarketing jasa layanan antar (Gambar 1).

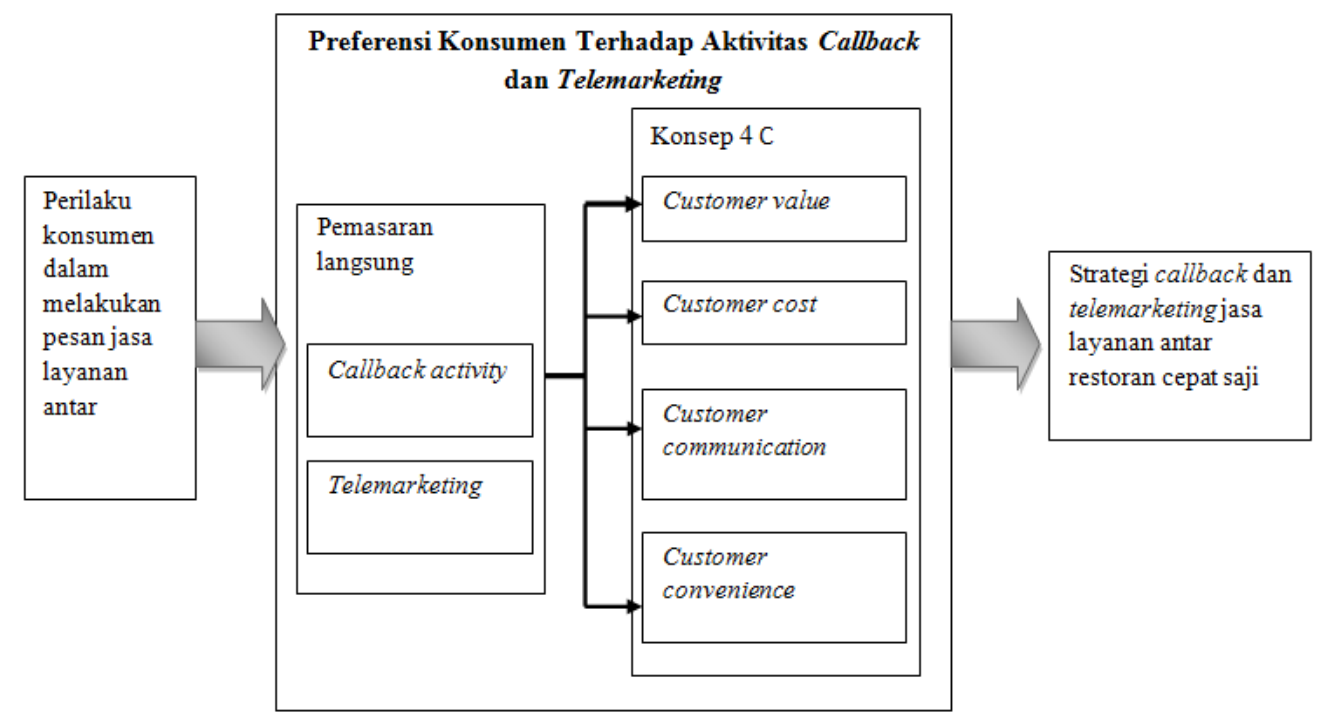

Gambar 1 Alur preferensi konsumen terhadap aktivitas callback dan telemarketing

Target aktivitas callback dan telemarketing disarankan pelanggan restoran atau konsumen yang pernah melakukan pesan jasa antar. Perilaku pelanggan dalam melakukan pemesanan menjadi data awal untuk memperoleh respon terhadap aktivitas pemasaran langsung. Respon ini dipetakan berdasarkan konsep $4 \mathrm{C}$, dan hasilnya dijadikan acuan bagi restoran dalam menyusun strategi untuk pelaksanaan aktivitas pemasaran langsung yang dimaksud.

Tabel 1 menggambarkan variabel pengukuran terhadap aktivitas callback dan telemarketing berdasarkan konsep $4 \mathrm{C}$ dengan mengacu pada jasa layanan antar dari restoran cepat saji. 
Tabel 1 Variabel Pengukuran Preferensi Konsumen terhadap Callback dan Telemarketing

\begin{tabular}{|c|c|c|}
\hline Variables & 4C Concept for delivery Service & $\begin{array}{c}\text { Company Offering for Callback \& Telemarketing } \\
\text { (Based on 4C concept) }\end{array}$ \\
\hline $\begin{array}{l}\text { Product as } \\
\text { Customer Value }\end{array}$ & $\begin{array}{l}\text { (1). Ketersediaan produk sesuai } \\
\text { yang dijanjikan; } \\
\text { (2). Jenis produk yang memenuhi } \\
\text { kebutuhan konsumen }\end{array}$ & $\begin{array}{l}\text { Adanya produk dan jasa yang ditawarkan dan } \\
\text { sesuai kebutuhan konsumen (memiliki nilai) }\end{array}$ \\
\hline $\begin{array}{l}\text { Price as Customer } \\
\text { Cost }\end{array}$ & $\begin{array}{l}\text { Harga sesuai yang dijanjikan } \\
\text { Harga dianggap } \quad \text { wajar oleh } \\
\text { konsumen }\end{array}$ & Biaya yang dikeluarkan oleh konsumen sepadan \\
\hline $\begin{array}{l}\text { Place as } \\
\text { Customer } \\
\text { Convenience }\end{array}$ & 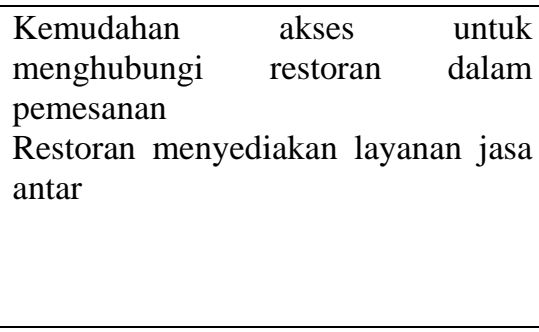 & $\begin{array}{l}\text { (1). Konsumen dihubungi pada waktu yang tepat; } \\
\text { (2). Perusahaan yang menghubungi dikenal } \\
\text { bereputasi baik; } \\
\text { (3). Konsumen memiliki ketertarikan pada produk } \\
\text { atau jasa; } \\
\text { (4). Konsumen memiliki pengalaman yang baik } \\
\text { dalam berhubungan dengan perusahaan } \\
\text { (restoran) }\end{array}$ \\
\hline $\begin{array}{l}\text { Promotion as } \\
\text { Customer } \\
\text { Communication }\end{array}$ & $\begin{array}{l}\text { Restoran menyediakan nomor akses } \\
\text { atau media lain untuk melakukan } \\
\text { pemesanan call back and } \\
\text { telemarketing }\end{array}$ & retention, call back, telemarketing \\
\hline
\end{tabular}

Gambar 2 berikut menjelaskan variabel dan konstruknya untuk kedua aktivitas tersebut:

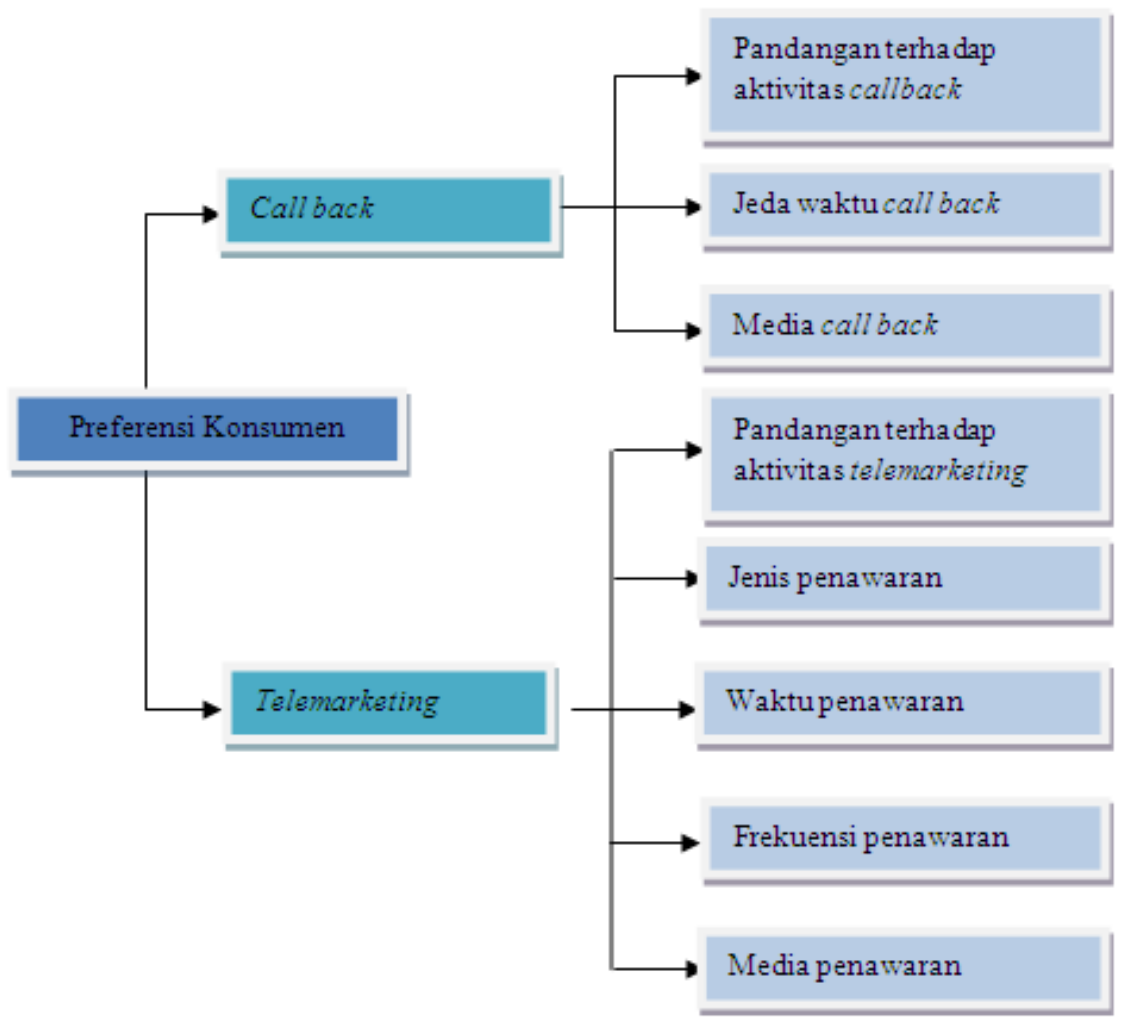

Gambar 2 Variabel penelitian yang digunakan 
Informasi yang perlu diketahui untuk melaksanakan aktivitas call back berupa 1) perilaku konsumen dalam melakukan panggilan untuk permintaan delivery service, 2) tanggapan konsumen jika perusahaan melakukan aktivitas call back atas panggilan tidak terjawab, 3) jeda waktu yang diharapkan antara waktu telpon tidak terjawab dengan aktivitas call back, dan 4) media callback yang lebih disukai oleh pelanggan

Informasi yang perlu diketahui untuk kegiatan telemarketing adalah 1) kegiatan telemarketing yang diterima dan dibutuhkan oleh konsumen (informasi produk atau penjualan), 2) waktu yang tepat untuk menelpon, 3) frekuensi kegiatan telemarketing kepada pelanggan, 4) serta media atau channel yang lebih disukai untuk aktivitas marketing yang dilakukan oleh perusahaan.

Alat ukur kemudian disusun yaitu terdiri dari daftar pertanyaan sebanyak 32 dengan komposisi: 8 (delapan) pertanyaan mengenai kebiasaan pemesanan, 6 (enam) pertanyaan mengenai preferensi terhadap produk, 1 (satu) pertanyaan mengenai aspek harga, 2 (dua) pertanyaan mengenai kemudahan akses, 1 (satu) pertanyaan mengenai penangan keluhan, empat pertanyaan mengenai preferensi aktivitas callback, empat pertanyaan mengenai preferensi waktu pemesanan, dan lima pertanyaan mengenai aktivitas telemarketing.

Pengujjian dilakukan terhadap alat ukur yang disusun dengan menyebarkannya kepada responden dengan teknik sampling purposives, yaitu responden yang dijadikan sampling adalah orangorang yang pernah atau sering melakukan pemesanan melalui jasa layanan antar. Alat ukur ini kemudian di sebarkan di Jakarta dengan lokasi pengumpulan data antara lain di daerah perumahan, daerah perbelanjaan dan lingkungan pendidikan. Jumlah kuesioner yang disebar 300 buah, kembali 287 dan yang terisi lengkap 267 buah, valid 259 buah. Responden terdiri dari $29.7 \%$ pria dan $70.3 \%$ wanita.

Berdasarkan hasil penyebaran kuesioner diperoleh bahwa Cronbach Alpha untuk ketigapuluh dua pertanyaan adalah 0.704 seperti pada Gambar 3 di bawah ini berdasarkan hasil pengolahan data dengan menggunakan SPPS:
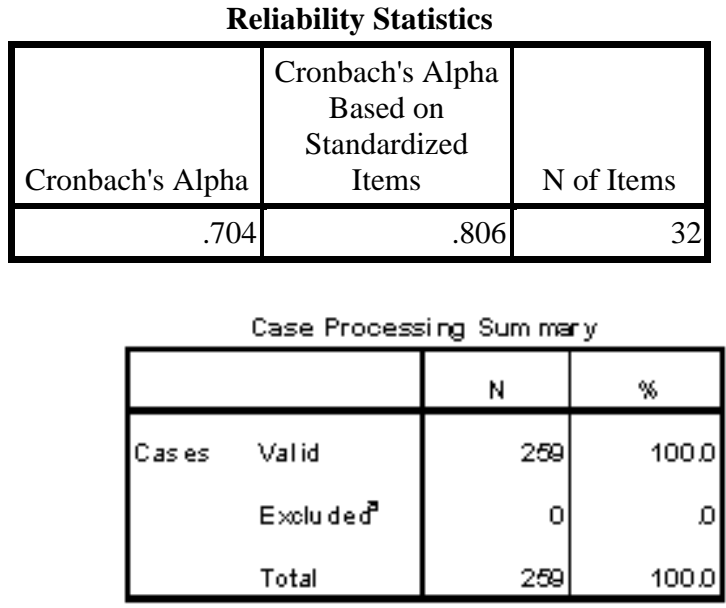

a. Lizbuie deletion based on all variables in the

propedure.

Gambar 3 Hasil perhitungan reliability (Alpha Cronbach) menggunakan SPSS

Dari hasil alpha cronbach sebesar 0.704, dapat dinyatakan bahwa alat ukur (kuesioner) ini realible untuk dijadikan sebagai pengukuran preferensi konsumen terhadap aktivitas callback dan telemarketing di sebuah jasa layanan antar. Penggunaan di masa yang akan datang sebagai dasar 
penentuan preferensi konsumen, akan memerlukan penyesuaian dan memerlukan pengukuran validitas dan realibilitasnya.

Profil responden berdasarkan usia dan pekerjaan dapat dilihat pada Gambar 4. Terlihat bahwa konsumen yang berada direntang usia 20-25 tahun adalah konsumen yang paling banyak melakukan pemesanan jasa layanan antar dan yang paling sedikit adalah konsumen di bawah usia 20 tahun. Berdasarkan pekerjaannya, karyawan merupakan konsumen yang paling banyak melakukan pemesanan, sementara self employee, ibu rumah tangga serta lainnya yang paling sedikit melakukan pemesanan.

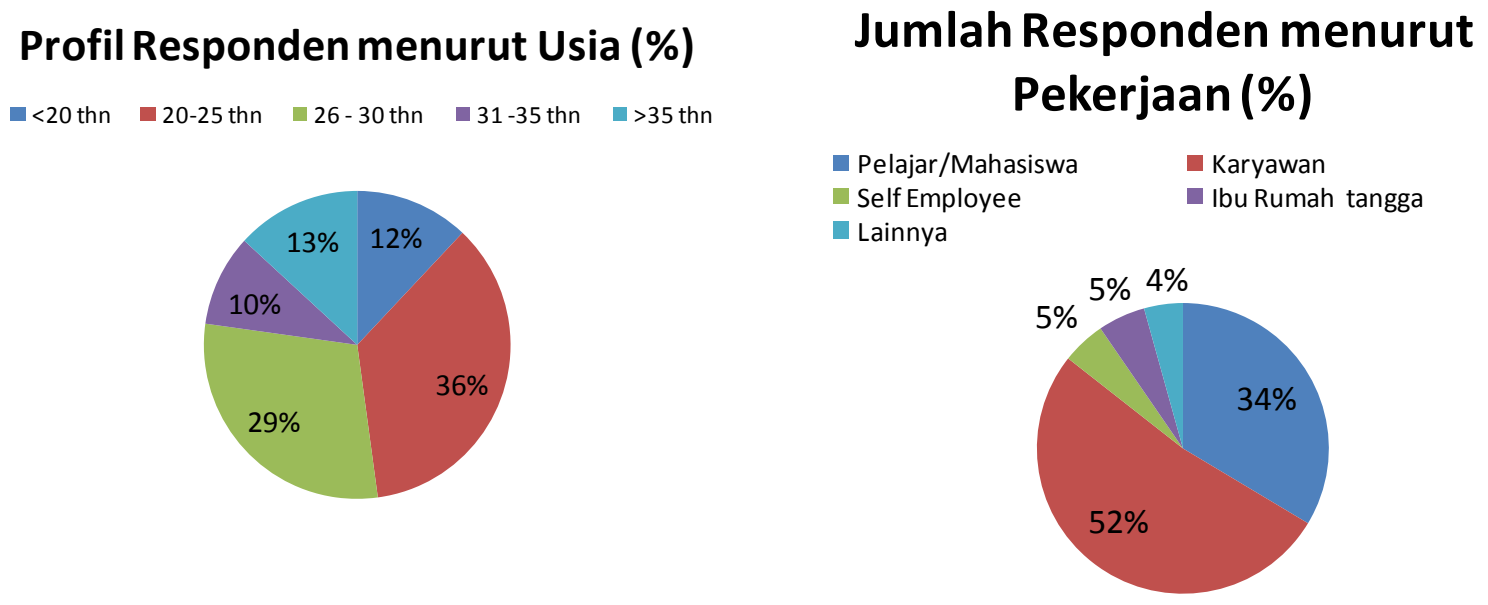

Gambar 4 Profil responden

Profil responden tentu saja akan dipengaruhi oleh basis pelanggan yang dimiliki oleh suatu usaha jika instrument ini diterapkan. Profil responden yang ditampilkan adalah sesuai dengan kriteria responden yang dimaksud dalam penelitian ini yaitu yang pernah melakukan pemesanan layanan jasa antar serta tinggal di Jakarta.

\section{PENUTUP}

Penelitian mengenai restoran dan perilaku konsumen sudah banyak dilakukan, begitu juga dengan penelitian mengenai aktivitas pemasaran termasuk komunikasi pemasaran dan dampaknya. Tetapi penelitian di area restoran waralaba cepat saji, masih sangat sedikit dilakukan, begitu juga tentang aktivitas pemasaran langsung yang dapat dijadikan strategi bersaing. Paper ini dimaksudkan sebagai usulan pengukuran preferensi konsumen terhadap aktivitas callback dan marketing di restoran khusus untuk aktivitas pemasaran langsung dari jasa layanan antar. Hal ini penting mengingat gerai jasa layanan antar sudah dijadikan gerai tersendiri bukan lagi sebagai layanan tambahan suatu restoran. Untuk selanjutnya model pengukuran perlu diimplementasikan dengan penyesuaian untuk melihat sejauh mana realibilitas model yang diusulkan, serta perbaikan apa yang dapat dilakukan agar diperoleh model yang baik. Diharapkan dengan dipetakan preferensi konsumen terhadap aktivitas tersebut, dapat dijadikan landasan bagi restoran waralaba untuk mengembangkan strategi kegiatan callback dan telemarketing yang sesuai dengan kebutuhan konsumen serta sumber daya yang dimiliki oleh perusahaan. 


\section{DAFTAR PUSTAKA}

Akbay, C., \& Tiryaki, G. Y. (2007). Consumer characteristics influencing fast food consumption in Turkey. Food Control , 18 (8), 904-913.

B.S, A. M., \& Nugroh, S. A. (2009, Juni 25). Demam Layanan Pesan Antar di Resto Cepat Saji. Diakses 5Maret 2012, dari Swasembada: http://202.59.162.82/cetak.php?cid=1\&id=9404\&url=http\%3A\%2F\%2F202.59.162.82\%2Fsw amajalah\%2Ftren\%2Fdetails.php\%3Fcid\%3D1\%26id\%3D9404

Batra., R., \& Ahtola, O. (1991). Measuring the hedonic and utilitarian sources of consumer attitudes. Marketing Letters 2, , 159-170.

Brezen, T. S., Block, M. P., \& Schultz, D. E. (1987). Consumers’ perceptions of direct marketing techniques. Journal of Direct Marketing, 38-49.

Cardello, A. V., Schutz, H., Snow, C., \& Lesher, L. (2000). Predictors of food acceptance, consumption and satisfaction in specific eating situations. Food Quality and Preference , 11 (3), 201-216.

Dagevos, H. (2005). Consumers as four-faced creatures. Looking at food consumption from the perspective of contemporary consumers. Appetite , 45 (1), 32-39.

Holbrook, M., \& Hirschman, E. (1982). The experiential aspects of consumption: consumer fantasies,. Journal of Consumer Research 9 , 132-140.

Kotler, P. (2005). According to Kotler. (H. Sudrajat, Trans.) Jakarta: Buana Ilmu Populer.

Kotler, P. (2003). Marketing Management. New Jersey: Prentice Hall.

Kumar, V., \& Venkatesan, R. (2005). Who are the multichannel shoppers and how do they perform?: Correlates of multichannel shopping behavior. Journal of Interactive Marketing , 19 (2), 4462 .

Lavidge, R. J., \& Steiner, G. A. (2000). A Model For Predictive Measurements of Advertising Effectiveness. Advertising \& Society Review , 1 (1).

Mulyadi, I. (2010, June 9). Teknologi dalam Call Center. Diakses 1 Agustus 2012, dari marketing.co.id: http://www.marketing.co.id/2010/06/09/teknologi-dalam-call-center/

Nowak, G. J., \& Phelps, J. (1997). Direct marketing and the use of individual-level consumer information: Determining how and when "privacy" matters. Journal of Interactive Marketing , 11 (4), 94-108.

Park, C. (2004). Efficient or enjoyable? Consumer values of eating-out and fast food restaurant consumption in Korea. International Journal of Hospitality Management , 23 (1), Pages 8794.

Pickworth, J. (1988). Service delivery systems in the food service industry. International Journal of Hospitality Management , 7 (1), 34-62. 
Stone, M., \& Shaw, R. (1987). Database marketing for competitive advantage. Long Range Planning , $20(2), 12-20$.

Suryanto. (2011, Agustus 9). Lebih Aktif dengan Contact Center Avaya. Diakses 4 Juli 2012, dari antaranews.com: center-avaya 